\title{
Weight-dependent susceptibility of tilapia to tilapia lake virus infection
}

Sri Rajiv Kumar Roy ${ }^{1}$, Jidapa Yamkasem ${ }^{1}$, Puntanat Tattiyapong ${ }^{1}$, Win Surachetpong ${ }^{\text {Corresp. } 1}$

${ }^{1}$ Department of Veterinary Microbiology and Immunology, Faculty of Veterinary Medicine, Kasetsart University, Kasetsart University, Bangkok, Thailand Corresponding Author: Win Surachetpong Email address: fvetwsp@ku.ac.th

The emergence of tilapia lake virus (TiLV) has had a severely negative impact on global tilapia aquaculture. TiLV infection has been reported at different life stages of tilapia, with more emphasis on fry and fingerlings; however, the virulence and pathology of TiLV at different tilapia size remains unexplored. In this study, tilapias from a single spawning were raised to $5 \mathrm{~g}, 25 \mathrm{~g}$, and $65 \mathrm{~g}$, and subsequently challenged by the intraperitoneal injection and cohabitation of a virulent strain of TiLV. The cumulative mortality, viral load, and histopathology of the fish were determined until 22 days post-infection (dpi). The cumulative mortality of the $5 \mathrm{~g}, 25 \mathrm{~g}$, and $65 \mathrm{~g}$ fish was $85 \%( \pm 1.67), 55 \%( \pm 2.89)$, and $51.67 \%$ ( \pm 7.49 ), respectively. At $14 \mathrm{dpi}$, the mean TiLV load in the liver of the $5 \mathrm{~g}$ fish was significantly higher than in the $25 \mathrm{~g}$ and $65 \mathrm{~g}$ fish. All the weight groups showed severe pathological changes in the liver, spleen, and intestine after TiLV infection, but no particular difference was otherwise noted during the study with the exception of higher pathological scores in the liver of the small fish at $14 \mathrm{dpi}$. Overall, this study indicated that small fish are more susceptible to TiLV infection than large fish. Although multiple factors, including environmental factors, farm management practices, strains of virus could contribute to different susceptibility of fish to viral infection, the present study provides the evidence to support that fish weight affects the mortality and clinical outcome during TiLV infection. More intensive measures such as strict biosecurity and disease surveillance during the susceptible weight should therefore be emphasized to reduce the impact of this virus. 
1 Title: Weight-dependent susceptibility of tilapia to tilapia lake virus infection

2 Sri Rajiv Kumar Roy ${ }^{1}$, Jidapa Yamkasem ${ }^{1}$, Puntanat Tattiyapong ${ }^{1}$, Win Surachetpong ${ }^{1}$

3

$4{ }^{1}$ Department of Veterinary Microbiology and Immunology, Faculty of Veterinary Medicine, 5 Kasetsart University, Bangkok, Thailand.

6

7 Corresponding author:

8 Win Surachetpong

9 Contact: Department of Veterinary Microbiology and Immunology, Faculty of Veterinary

10 Medicine, Kasetsart University, 50 Ngam Wong Wan Road, Ladyao, Chatuchak, Bangkok,

1110900 Thailand. Phone number: +66 029428436

12 Email address: fvetwsp@ku.ac.th 


\section{Abstract}

14 The emergence of tilapia lake virus (TiLV) has had a severely negative impact on global tilapia 15 aquaculture. TiLV infection has been reported at different life stages of tilapia, with more emphasis 16 on fry and fingerlings; however, the virulence and pathology of TiLV at different tilapia size

17 remains unexplored. In this study, tilapias from a single spawning were raised to $5 \mathrm{~g}$, $25 \mathrm{~g}$, and 65 g, and subsequently challenged by the intraperitoneal injection and cohabitation of a virulent strain of TiLV. The cumulative mortality, viral load, and histopathology of the fish were determined until 22 days post-infection (dpi). The cumulative mortality of the $5 \mathrm{~g}, 25 \mathrm{~g}$, and $65 \mathrm{~g}$ fish was $85 \%$ $( \pm 1.67), 55 \%( \pm 2.89)$, and $51.67 \%( \pm 7.49)$, respectively. At $14 \mathrm{dpi}$, the mean TiLV load in the liver of the $5 \mathrm{~g}$ fish was significantly higher than in the $25 \mathrm{~g}$ and $65 \mathrm{~g}$ fish. All the weight groups showed severe pathological changes in the liver, spleen, and intestine after TiLV infection, but no particular difference was otherwise noted during the study with the exception of higher pathological scores in the liver of the small fish at 14 dpi. Overall, this study indicated that small fish are more susceptible to TiLV infection than large fish. Although multiple factors, including environmental factors, farm management practices, strains of virus could contribute to different susceptibility of fish to viral infection, the present study provides the evidence to support that fish weight affects the mortality and clinical outcome during TiLV infection. More intensive measures such as strict biosecurity and disease surveillance during the susceptible weight should therefore

31 be emphasized to reduce the impact of this virus. 
32

33

34

35

Tilapia is the second most cultured fish species worldwide, with an annual production of 6.4 million tons and a projected value of 9.8 billion USD (Food and Agriculture Organization [ FAO], 2017). The popularity of tilapia aquaculture has expanded rapidly due to the tilapia's affordability, status as a high-quality protein source, strong disease resistance, and easy adaptation to adverse environments. However, the recent detection of tilapia lake virus (TiLV) is having a significant impact on tilapia production (Eyngor et al., 2014; FAO, 2017; World Organisation for Animal Health [OIE], 2018; Surachetpong, Roy, \& Nicholson, 2020). The virus causes high mortality in tilapia up to $90 \%$ in cases of natural infection and is responsible for the immensely negative economic impact on tilapia production in several countries (Fathi et al., 2017; Surachetpong et al., 2017). TiLV has been identified in 16 countries across four different continents (Surachetpong et al., 2020). A recent genomic analysis characterized TiLV in the new genus Tilapinevirus and species Tilapia tilapinevirus under the family Amnoonviridae and order Articulavirales (Adams et al., 2017).

The life stage or weight of fish at the time of exposure to pathogens is an important factor influencing mortality (Bergmann, Fichtner, Skall, Schlotfeldt, \& Olesen, 2003; Jaramillo, Hick, \& Whittington, 2017; Sollid, Lorz, Stevens, \& Bartholomew, 2003). In general, juvenile fish are more susceptible to viruses, bacteria, or parasites than adult fish. For instance, most strains of infectious hematopoietic necrosis virus (IHNV) cause high mortality in small (2-20 g) rainbow trout (Oncorhynchus mykiss) than large (50 g) fish (Bergmann et al., 2003). Moreover, subclinical infection of nervous necrosis virus (NNV) in barramundi (Lates calcarifer) occurs in fish at five, seven, and nine weeks, while mass mortality and more severe clinical signs develop in small fish at three to four weeks, suggesting the impact of the age of the host during exposure to pathogens 
55 (Jaramillo et al., 2017). There have been no detailed studies on the weight or life stage-related 56 susceptibility of tilapia to TiLV although it has suggested that all life stages of tilapia, including

57 fertilized eggs, fry, juveniles, adult, and brood stock, are prone to TiLV infection (Dong, Ataguba, 58 Khunrae, Rattanarojpong, \& Senapin, 2017; Yamkasem, Tattiyapong, Kamlangdee, \& 59 Surachetpong, 2019). It has been reported that during field outbreaks, juvenile fish and fingerlings 60 at the weights $1-10 \mathrm{~g}$ are more susceptible to infection than adult fish $(>100 \mathrm{~g})$ (Eyngor et al., 61 2014; Jansen, Dong, \& Mohan, 2019; Tattiyapong, Dachavichitlead, \& Surachetpong, 2017).

62 Likewise, high mortality $(20 \%-90 \%)$ associated with TiLV infection has been described in small 63 fish (1-50 g) (Surachetpong et al., 2017), while low mortality (9.2\%) has been observed in adult 64 tilapia (Fathi et al., 2017). In laboratory challenge studies, mortality ranging from $45 \%$ to $100 \%$ 65 has been recorded in juvenile Nile tilapia and red hybrid tilapia at 10-15 g (Behera et al., 2018; 66 Eyngor et al., 2014; Liamnimitr, Thammatorn, U-thoomporn, Tattiyapong, \& Surachetpong, 2018;

67 Tattiyapong et al., 2017)). In the present study, the impact of weight on the susceptibility of tilapia to TiLV was investigated. The cumulative mortality, viral load, and pathology after intraperitoneal (IP) injection and cohabitation challenge by TiLV were examined. Our findings suggest that fish weights influence the outcome during TiLV infection.

\section{Materials and Methods}

\section{Animals and experimental designs}

In total, 400 red tilapia hybrid (Oreochromis spp.) with an initial body weight of $1.0 \pm 0.1 \mathrm{~g}$ were acquired from a tilapia hatchery with a TiLV-free status from Petchaburi province, Thailand. The 
77 University, Bangkok, Thailand, in $400 \mathrm{~L}$ tanks at $28^{\circ} \mathrm{C}$ with daily water exchanges up to $50 \%$.

78 After one week of acclimatization, five fish were randomly selected for screening for important 79 pathogens, including TiLV by reverse transcription-quantitative PCR (RT-qPCR), bacterial 80 isolation by anterior kidney sampling, and parasites by skin scraping and gill excision. Fish were 81 fed with commercial feed three times per day until reaching an average size of $5 \mathrm{~g}, 25 \mathrm{~g}$, and $65 \mathrm{~g}$.

82 The average age of $5 \mathrm{~g}, 25 \mathrm{~g}$, and $65 \mathrm{~g}$ fish were 8,12 , and 16 weeks respectively. At the same 83 density (5 g/L), sixty fish from each weight group were equally divided into two $150 \mathrm{~L}$ tanks (for $845 \mathrm{~g}$ fish), three $150 \mathrm{~L}$ tanks (for $25 \mathrm{~g}$ fish), and six $150 \mathrm{~L}$ tanks (for $65 \mathrm{~g}$ fish). These tanks were 85 dedicated to recording mortality. A further 30 fish of $5 \mathrm{~g}, 25 \mathrm{~g}$, and $65 \mathrm{~g}$ were placed in additional $150 \mathrm{~L}$ tanks at the same density for sample collection. For each weight group, an additional 15 fish were used as the control group. The animal use protocol was approved by the Kasetsart University Institutional Animal Care and Use Committee (protocol number ACKU63-VET-011).

\section{Virus propagation and challenge study}

The TiLV strain VETKU-TV08 isolated from red hybrid tilapia collected in 2019 was used in the challenge study. The virus was propagated in the E-11 cell line, which is a clone of SSN-1 from snakehead fish (Ophicephalus striatus). The E-11 cell line was purchased from the European Collection of Authenticated Cell Cultures (ECACC, Porton Down, Salisbury, UK). The E-11 cells were maintained in Leibovitz's L-15 medium (Sigma-Aldrich, St. Louis, MO, USA) and supplemented with 5\% (vol/vol) fetal bovine serum (Thermo Fisher Scientific, Waltham, MA, USA) and $2 \mathrm{mM} \mathrm{L-glutamine.} \mathrm{The} \mathrm{cells} \mathrm{were} \mathrm{propagated} \mathrm{at} 25^{\circ} \mathrm{C}$ without $\mathrm{CO}_{2}$. The infected E-11 cells were harvested through centrifugation at $3000 \times g$ for $10 \mathrm{~min}$, and the supernatant was then collected and stored at $-80^{\circ} \mathrm{C}$ for later use. Before the IP injection challenge, the fish were sedated with a $1 \mathrm{~mL} / \mathrm{L}$ eugenol (Better Pharma, Bangkok, Thailand) solution for $3 \mathrm{~min}$. The fish were IP- 
100 challenged with $50 \mu \mathrm{L}$ of TiLV at $10^{5} \mathrm{TCID}_{50} / \mathrm{mL}$ or the $\mathrm{L}-15$ medium for the control group.

101 During the experiment, the decision criteria to terminate fish included the appearance of severe

102 clinical signs with two or more appearance including stop feeding for three consecutive days,

103 severe erratic swimming, skin erosion, skin hemorrhage, scale protrusion, extensive abdominal

104 swelling, and exophthalmia. For viral quantification, the liver tissues were collected from the

105 control fish $(n=3)$ at day 0 of all weight groups and TiLV IP-challenge fish $(n=7-8)$ at 7,14 ,

106 and 22 days post-infection (dpi). The fish were euthanized using an overdose of eugenol solution

107 (3 $\mathrm{mL} / \mathrm{L})$ for $5 \mathrm{~min}$ prior to fish necropsy and sample collection. The samples were placed in 108 separate $1.5 \mathrm{~mL}$ microcentrifuge tubes, and stored at $-20^{\circ} \mathrm{C}$ for further RNA isolation.

109 For the cohabitation study, 10 fish of $5 \mathrm{~g}$ and $25 \mathrm{~g}$ were IP-injected with $50 \mu \mathrm{L}$ of the TiLV strain

110 VETKU-TV08 at $10^{5} \mathrm{TCID}_{50} / \mathrm{mL}$ and then placed in a $150 \mathrm{~L}$ glass tank containing 30 fish

111 (cohabitation fish) of either $5 \mathrm{~g}$ or $25 \mathrm{~g}$ fish, giving a ratio of inducer to cohabitant of 1:3

112 (Liamnimitr et al., 2018). All IP-injected fish (inducer) were trimmed on the pelvic fin to

113 differentiate them from cohabitating fish. Clinical signs of infection and cumulative mortality were

114 observed and recorded until 28 days post challenge. At 7 and 14 dpi, three cohabitation fish from

115 the $5 \mathrm{~g}$ and $25 \mathrm{~g}$ groups were randomly euthanized to collect liver samples and for processing for

116 RNA isolation.

\section{RNA extraction and cDNA synthesis}

118 The total RNA was extracted from the liver using GENEzol ${ }^{\mathrm{TM}}$ reagent (Geneaid Biotech Ltd., New

119 Taipei City, Taiwan) according to the manufacturer's instructions. Briefly, $30 \mathrm{mg}$ of liver samples

120 were mixed and homogenized in $1 \mathrm{~mL}$ of GENEzol ${ }^{\mathrm{TM}}$ reagent using a hand-held pestle

121 homogenizer. Thereafter, $200 \mu \mathrm{L}$ of chloroform was mixed and incubated at room temperature for

$1223 \mathrm{~min}$. The samples were then centrifuged at $4^{\circ} \mathrm{C}$ and $12,000 \times g$ for $15 \mathrm{~min}$. The supernatant was 
123 transferred to a new microcentrifuge tube, mixed with $500 \mu \mathrm{L}$ isopropanol, and incubated at $-20^{\circ} \mathrm{C}$

124 for $2 \mathrm{~h}$. The samples were centrifuged at $4^{\circ} \mathrm{C}$ and $12,000 \times g$ for 15 min to precipitate the RNA.

125 After discarding the supernatant, the RNA pellet was washed with $75 \%$ ethanol and centrifuged at

$1264^{\circ} \mathrm{C}$ and $10,000 \times g$ for $15 \mathrm{~min}$. The RNA pellet was resuspended in $50 \mu \mathrm{L}$ prewarmed RNase-free

127 water $\left(60^{\circ} \mathrm{C}\right)$. The RNA quality and quantity were examined using a NanoDrop 2000

128 spectrophotometer (Thermo Fisher Scientific, Waltham, MA, USA).

129 For cDNA synthesis, a $20 \mu \mathrm{L}$ mix reaction containing $4 \mu \mathrm{L}$ of $5 \mathrm{X}$ RT buffer mix, $1 \mu \mathrm{L}$ of primer 130 mix, $1 \mu \mathrm{L}$ of RT enzyme mix, $4 \mu \mathrm{L}$ of nuclease-free water, and $10 \mu \mathrm{L}$ total RNA template $(1 \mu \mathrm{g})$

131 was prepared using a reverse transcription kit (Toyobo, Osaka, Japan). The reaction was incubated 132 in a T100 thermal cycler (Bio-Rad, Hercules, CA, USA) at $42^{\circ} \mathrm{C}$ for $60 \mathrm{~min}$, followed by $98^{\circ} \mathrm{C}$ for $1335 \mathrm{~min}$.

\section{Reverse transcription-quantitative polymerase chain reaction}

The TiLV genomic RNA was measured using an SYBR-based reverse transcription-quantitative polymerase chain reaction (RT-qPCR) assay (Tattiyapong, Sirikanchana, \& Surachetpong, 2018).

Briefly, the reaction was performed in a $10 \mu \mathrm{L}$ reaction containing $4 \mu \mathrm{L}$ of $400 \mathrm{ng}$ cDNA, $5 \mu \mathrm{L}$ of 2X iTaq $^{\mathrm{TM}}$ universal SYBR supermix (Bio-Rad, Hercules, CA, USA), and $0.3 \mu \mathrm{L}$ of forward and reverse primers. The final volume was adjusted to $10 \mu \mathrm{L}$ using molecular water. The reactions were performed in a PCR thermal cycler, CFX96 Touch ${ }^{\mathrm{TM}}$ (Bio-Rad, Hercules, CA, USA). At the end of the qPCR reaction, the samples were processed for melting curve analysis at $65^{\circ} \mathrm{C}-95^{\circ} \mathrm{C}$ with increments of $0.5^{\circ} \mathrm{C}$ per $5 \mathrm{~s}$. The TiLV viral concentration was extrapolated by comparing

143 the $\mathrm{Ct}$ value of the tested samples to the standard curve generated from a 10-fold serial dilution of 144 a plasmid-containing segment 3 of TiLV. 


\section{Histopathology}

146 For the histopathological analysis, two control and three TiLV IP-challenge fish were collected

147 from each weight group at 7, 14, and 22 dpi. Tissues, including the liver, spleen, and intestine, 148 were removed and placed in $10 \%$ (vol/vol) neutral buffered formalin. At $24 \mathrm{~h}$, the tissues were 149 transferred to $70 \%$ ethanol. The samples were then processed using a standard histopathology 150 protocol in which they were embedded in the paraffin block, sectioned at $5 \mu \mathrm{M}$ thick, and stained 151 with hematoxylin and eosin (H\&E). Thereafter, the tissue slides were scanned using VS120 ${ }^{\circledR}$ 152 Virtual Microscopy Slide Scanning (Olympus, Japan) and examined and graded under an Olympus 153 OlyVIA Ver.3.1 program (Olympus, Japan).

154 Statistical analysis

155 The difference in the cumulative mortality, and mean TiLV concentration in the IP-challenge and 156 cohabitation experiments, pathological scores from each weight groups and different time points 157 were determined using GraphPad Prism software version 5.0 (GraphPad, San Diego, CA, USA). 158 Significant differences were assessed using one-way ANOVA with Tukey's multiple comparisons test or nonparametric Mann-Whitney test (Gibson-Corley, Olivier, \& Meyerholz, 2013). A p-value 160 less than 0.05 was considered significant.

\section{Results}

Susceptibility of small fish to TiLV infection.

After TiLV infection, an earlier onset of clinical signs, including lethargy, anorexia, schooling 165 cessation, and lying on the floor of the tank, was observed in the small fish $(5 \mathrm{~g})$ at 2 dpi, while 
166 these clinical signs started at $4 \mathrm{dpi}$ in the medium (25 g) and large fish (65 g). More severe clinical

167 signs and gross lesions, including exophthalmos, skin hemorrhage, scale protrusion, anemia, fin 168 erosion, and ascites, were exhibited in all weight groups after 4 dpi (Supplementary Information 169 Fig. S1). At the end of the experiment, the mean cumulative mortality and standard error of the 170 mean (SE) of the small, medium, and large red hybrid tilapia was $85 \%( \pm 1.67), 55 \%( \pm 2.89)$, and $17151.67 \%( \pm 7.49)$, respectively, with significantly higher mortality in the $5 \mathrm{~g}$ fish than the other 172 groups $(p<0.05$; Fig. 1). The small fish had first mortality at 3 dpi, while this occurred in the 173 medium and large fish at 7 dpi. Notably, the mortality of the small fish continued until 16 dpi, 174 while the mortality of the medium and large fish stopped at 13 and 14 dpi, respectively. No 175 mortality or signs of TiLV infection were recorded in the control fish in any weight group at any 176 time during the study.

\section{Amount of TiLV in small fish.}

At 7 dpi, the mean TiLV genomic RNA concentration in the liver of the $5 \mathrm{~g}, 25 \mathrm{~g}$, and $65 \mathrm{~g}$ fish

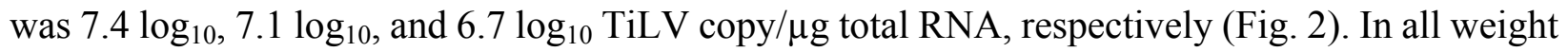
groups, the mean viral load at 14 dpi was significantly lower at $5.7 \log _{10}, 2.7 \log _{10}$, and $3.1 \log _{10}$

TiLV copy/ $\mu \mathrm{g}$ total RNA in the $5 \mathrm{~g}, 25 \mathrm{~g}$, and $65 \mathrm{~g}$ fish, respectively. No difference in the mean viral load was found at $22 \mathrm{dpi}\left(3.4 \log _{10}, 3.2 \log _{10}\right.$, and $3.0 \log _{10}$ TiLV copy/ $\mu$ g total RNA in the 5 genomic RNA in the liver than the $25 \mathrm{~g}$ fish $(p<0.001)$ and $65 \mathrm{~g}$ fish $(p<0.01)$ at $14 \mathrm{dpi}$ (Fig. 2). challenge. 
188 Histopathological changes in the liver, spleen, and intestine of all the weight groups were scored 189 according to the scoring system described in Table 1 and Figure 3. The scores were given after 190 examining three fish per weight group per time point. The three categories of scores were normal 191 (0), mild (1), moderate (2), and severe (3) (Supplementary Information Fig. S2). At 7 dpi, all the 192 weight groups obtained severe pathological scores in the liver, spleen, and intestine. At 14 dpi, 193 lower pathological scores were given for the liver, spleen, and intestine of the $25 \mathrm{~g}$ and $65 \mathrm{~g}$ fish 194 than the $5 \mathrm{~g}$ fish. In particular, most of the $5 \mathrm{~g}$ fish had moderate or severe pathological scores in 195 these organs compared to the $25 \mathrm{~g}$ and $65 \mathrm{~g}$ fish (Table 2). Low histopathological scores were 196 obtained in all weight groups at 22 dpi (data not shown) and no pathological changes in the control 197 unchallenged fish.

Weight susceptibility to TiLV in the cohabitation challenge.

199

200

201

202

203

204

205

206

207

208

209

210

The effect of weight on TiLV susceptibility was further tested in the cohabitation challenge study. As shown in Figure 4, the cumulative mortality of the inducer $5 \mathrm{~g}$ and $25 \mathrm{~g}$ fish were $85 \%$ and $60 \%$, respectively, while the mortality in the cohabitation $5 \mathrm{~g}$ and $25 \mathrm{~g}$ fish was $38 \%$ and $23 \%$, respectively. Both the inducer $5 \mathrm{~g}$ and $25 \mathrm{~g}$ fish started showing clinical signs of TiLV infection on days 3-4, with the first mortality observed on $7 \mathrm{dpi}$. Notably, the cohabitation $5 \mathrm{~g}$ and $25 \mathrm{~g}$ fish had delayed clinical signs and mortality onset, which started on 9-11 dpi. Interestingly, while the mortality in the $5 \mathrm{~g}$ fish ceased at 20-24 dpi, the mortality of the $25 \mathrm{~g}$ fish stopped earlier, at 1518 dpi (Fig. 4). Further analysis of the TiLV concentrations in the liver of the cohabitation $5 \mathrm{~g}$ fish at 7 and 14 days showed the viral load between $3.50 \log _{10}$ and $5.64 \log _{10}$ TiLV copy/ $\mu$ g total RNA. The mean viral load in cohabitation $25 \mathrm{~g}$ fish ranged between $2.86 \log _{10}$ and $5.71 \log _{10} \mathrm{TiLV}$ copy $/ \mu \mathrm{g}$ total RNA. 


\section{Discussion}

212 Since 2014, TiLV has had severely negative impacts on global tilapia aquaculture (Surachetpong

213 et al., 2020). To overcome the negative impacts of TiLV disease, it is necessary to identify the

214 associated risk factors and to implement appropriate interventions. In this study, our results

215 revealed that small tilapia are more susceptible to TiLV infection than large tilapia. Specifically,

216 higher mortality and worse clinical signs were observed in the $5 \mathrm{~g}$ fish than the $25 \mathrm{~g}$ and $65 \mathrm{~g}$ fish.

217 High mortality (above 50\%) after TiLV infection has been observed consistently in experimentally

218 challenged tilapia (Behera et al., 2018; Tattiyapong et al., 2017). In conditions of natural infection,

219 TiLV can cause mortality ranging from 5\% to $90 \%$ depending on multiple factors (e.g., co-

220 infections with other pathogens and farm biosecurity practices) (Eyngor et al., 2014; Fathi et al.,

221 2017; Nicholson et al., 2017; Nicholson, Mon-on, Jaemwimol, Tattiyapong, \& Surachetpong,

222 2020; Surachetpong et al., 2017). A recent field outbreak investigation revealed high mortality

$223(80 \%)$ in $10 \mathrm{~g}$ tilapia, with lower mortality (50\%) recorded in $120 \mathrm{~g}$ tilapia (Rao et al., 2021).

224 Similar to TiLV, the life stage of the salmonid species plays an important role in their susceptibility

225 to IHNV infection. For instance, small fish up to two months of age are more susceptible to IHNV

226 than adult salmon (Lapatra, 1998). Likewise, Bergmann et al. (Bergmann et al., 2003) reported

227 lower mortality in 40-50 g rainbow trout (Oncorhynchus mykiss) than 2.5-3 g and 15-20 g fish

228 after exposure to different isolates of IHNV. Moreover, the impact of fish age for viral

229 susceptibility has been highlighted in common carp, salmonid species, cyprinid species and percid

230 species against spring viremia of carp virus (Embregts et al., 2017; Emmenegger et al., 2016).

231 Under field conditions, TiLV disease frequently occurs when tilapias are at 1-80 g, the period

232 when the farmers often stock fish in the farms. As such, we focused our study on the susceptibility

233 of TiLV infection in 5-65 g fish. Indeed, multiple factors, including environmental factors, farm 
234 management practices, age and genetic of fish, and strains of virus could contribute to different 235 susceptibility of fish to viral infection. Our study provides the evidence as to support field 236 observation that younger fish being more susceptible to TiLV infection.

237 Susceptibility due to the weight of tilapia during TiLV infection was further confirmed in this 238 study using RT-qPCR and histopathological analysis. The $5 \mathrm{~g}, 25 \mathrm{~g}$, and $65 \mathrm{~g}$ fish had high viral 239 loads at $7 \mathrm{dpi}$, but this declined dramatically to low but detectable levels at 22 dpi. Significantly, 240 higher TiLV concentrations were detected in the livers of the $5 \mathrm{~g}$ fish than the $25 \mathrm{~g}$ and $65 \mathrm{~g}$ fish 241 at 14 dpi. In the small tilapia, severe histopathological changes were found in multiple organs 242 compared to fewer lesions in the large tilapia. The severe pathological changes and extensive viral 243 replication could have overcome the hosts' immune systems, thus contributing to the high 244 mortality of the $5 \mathrm{~g}$ fish. A correlation between high viral load and mortality was demonstrated in 245 Nile tilapia after a TiLV challenge via an intragastric route (Pierezan, Yun, Piewbang, 246 Surachetpong, \& Soto, 2020). Additionally, a correlation between the histopathological changes 247 and the level of viral load has been reported in Atlantic salmon (Salmo salar L.) after exposure to 248 the piscine myocarditis virus (Timmerhaus et al., 2011). Overall, these evidences suggest that a 249 high viral load and severe pathological alterations contribute to high mortality in small fish during 250 virus infection.

251 To reflect natural infection and further validate the impact of fish size during TiLV infection, we 252 produced TiLV infection in $5 \mathrm{~g}$ and $25 \mathrm{~g}$ tilapia through a cohabitation challenge model. Both the 253 inducer and cohabitating $5 \mathrm{~g}$ tilapia showed higher mortality rates than the inducer and 254 cohabitating $25 \mathrm{~g}$ tilapia. Conceivably, the resistance in the $25 \mathrm{~g}$ fish could be partly explained by 255 its different immune functions, which could play an important role in the control of virus 256 replication in adult fish. Various factors and mechanisms such as differences in innate immunity 
257 or host cell permissiveness are likely involved in weight-dependent susceptibility to TiLV

258 infection. Prior to this study, a different expression of cytokines and immune-related genes was

259 reported in tilapia during TiLV infection (Mugimba et al., 2020; Pierezan et al., 2020; Sood et al.,

260 2021). For example, Mugimba et al.(2020) showed that the TiLV viral load and expression of

261 immune-related genes were inversely correlated in the brain and spleen of infected fish.

262 Alternatively, a mechanism to facilitating viral persistence in younger fish e.g., production of

263 immunosuppressive cytokines, could play a role in suppressing the host response to TiLV.

264 Nevertheless, further study is required to dissect the mechanisms of host immunity in different

265 sizes of fish against TiLV. In addition to the different immune regulation, the challenge route,

266 strain of the virus, and condition of the fish could affect the outcomes of challenge studies (Eyngor

267 et al., 2014; Liamnimitr et al., 2018; Mugimba et al., 2019; Pierezan et al., 2020; Tattiyapong et

268 al., 2017). Understanding the stage at which fish are susceptible to pathogens could lead to the

269 appropriate implementation of control measures during critical periods in fish aquaculture. Such

270 control measures, including the probiotic Bacillus spp. or immunostimulants, could be applied to

271 promote the immune system of the host prior to TiLV exposure. The positive effects of probiotics

272 was highlighted in a recent study, which showed that probiotic supplementation with Bacillus spp.

273 in tilapia feed improved fish survival while reducing the TiLV load in the organs of fish

274 (Waiyamitra et al., 2020).

276 Conclusions

277 Our study demonstrated that fish weight strongly influences the outcome of TiLV infection. High mortality, an abundant viral load, and severe pathological changes were found in the small fish

279 rather than the large fish. The application of control measures such as supplementation with 
280 probiotics or immunostimulants during the life stage or weight when tilapia are most at risk of

281 infection could therefore help farmers cope with the negative impacts of TiLV.

Additional Information and Declarations

\section{Conflict of Interest}

Authors declare no conflict of interest.

\section{Author Contributions}

287 288 289

Sri Rajiv Kumar Roy conceived and designed the experiments, performed the experiments, analyzed the data, prepared figures and table, authored and reviewed drafts of the paper, approved the final draft.

Jidapa Yamkasem analyzed the data, prepared figures, authored and reviewed drafts of the paper, approved the final draft.

Puntanat Tattiyapong performed the experiments, analyzed the data, prepared figures, authored and reviewed drafts of the paper, approved the final draft.

Win Surachetpong conceived and designed the experiments, analyzed the data, prepared figures and table, authored and reviewed drafts of the paper, approved the final draft and supervised the study.

\section{Data Availability}

The data that support the findings of this study are available from the corresponding author upon reasonable request. 
301

302

303

304

305

306

307

308

309

310

311

312

313

314

315

316

317

318

319

320

321

322

323

324

325

326

327

328

329

330

331

332

333

334

\section{Acknowledgements}

This research is supported by the Kasetsart University Research and Development Institute under

project number $\mathrm{FF}(\mathrm{KU})$ 25.64. This research is supported by the Graduate Program Scholarship from The Graduate School, Kasetsart University. There was no additional external funding received for this study.

\section{References}

Adams, M. J., Lefkowitz, E. J., King, A. M. Q., Harrach, B., Harrison, R. L., Knowles, N. J., . . . Davison, A. J. (2017). Changes to taxonomy and the International Code of Virus Classification and Nomenclature ratified by the International Committee on Taxonomy of Viruses (2017). Archives of Virology, 162(8), 2505-2538. doi:10.1007/s00705-017-33585

Behera, B. K., Pradhan, P. K., Swaminathan, T. R., Sood, N., Paria, P., Das, A., . . Jena, J. K. (2018). Emergence of Tilapia Lake Virus associated with mortalities of farmed Nile Tilapia Oreochromis niloticus (Linnaeus 1758) in India. Aquaculture, 484, 168-174. doi:https://doi.org/10.1016/j.aquaculture.2017.11.025

Bergmann, S. M., Fichtner, D., Skall, H. F., Schlotfeldt, H. J., \& Olesen, N. J. (2003). Age- and weight-dependent susceptibility of rainbow trout Oncorhynchus mykiss to isolates of infectious haematopoietic necrosis virus (IHNV) of varying virulence. Diseases of Aquatic Organisms, 55(3), 205-210. doi:10.3354/dao055205

Dong, H. T., Ataguba, G. A., Khunrae, P., Rattanarojpong, T., \& Senapin, S. (2017). Evidence of TiLV infection in tilapia hatcheries from 2012 to 2017 reveals probable global spread of the disease. Aquaculture, 479, 579-583. doi:https://doi.org/10.1016/j.aquaculture.2017.06.035

Embregts, C. W. E., Rigaudeau, D., Vesely, T., Pokorova, D., Lorenzen, N., Petit, J., . . Forlenza, M. (2017). Intramuscular DNA vaccination of juvenile carp against Spring Viremia of Carp Virus induces full protection and establishes a virus-specific $\mathrm{B}$ and $\mathrm{T}$ Cell response. Frontiers in Immunology, 8, 1340. doi:10.3389/fimmu.2017.01340

Emmenegger, E. J., Sanders, G. E., Conway, C. M., Binkowski, F. P., Winton, J. R., \& Kurath, G. (2016). Experimental infection of six North American fish species with the North Carolina strain of spring Viremia of Carp Virus. Aquaculture, 450, 273-282. doi:https://doi.org/10.1016/j.aquaculture.2015.07.007

Eyngor, M., Zamostiano, R., Kembou Tsofack, J. E., Berkowitz, A., Bercovier, H., Tinman, S., . . . Eldar, A. (2014). Identification of a novel RNA virus lethal to tilapia. Journal of Clinical Microbiology, 52(12), 4137-4146. doi:10.1128/JCM.00827-14 
FAO. (2017). Outbreaks of Tilapia lake virus (TiLV) threaten the livelihoods and food security of millions of people dependent on tilapia farming. Retrieve from http://www.fao.org/documents/card/en/c/3ce1da5b-1529-4e7c-8b88-7adfef8d138c/

Fathi, M., Dickson, C., Dickson, M., Leschen, W., Baily, J., Muir, F., .. . Weidmann, M. (2017). Identification of Tilapia Lake Virus in Egypt in Nile tilapia affected by 'summer mortality' syndrome. Aquaculture, 473, 430-432. doi:https://doi.org/10.1016/j.aquaculture.2017.03.014

Gibson-Corley, K. N., Olivier, A. K., \& Meyerholz, D. K. (2013). Principles for valid histopathologic scoring in research. Veterinary Pathology, 50(6), 1007-1015. doi: $10.1177 / 0300985813485099$

Jansen, M. D., Dong, H. T., \& Mohan, C. V. (2019). Tilapia lake virus: a threat to the global tilapia industry? Reviews in Aquaculture, 11(3), 725-739. doi:10.1111/raq.12254

Jaramillo, D., Hick, P., \& Whittington, R. J. (2017). Age dependency of nervous necrosis virus infection in barramundi Lates calcarifer (Bloch). Journal of Fish Diseases, 40(8), 10891101. doi:10.1111/jfd.12584

Lapatra, S. E. (1998). Factors affecting pathogenicity of Infectious Hematopoietic Necrosis Virus (IHNV) for salmonid fish. Journal of Aquatic Animal Health, 10(2), 121-131. doi:https://doi.org/10.1577/1548-8667(1998)010<0121:FAPOIH>2.0.CO;2

Liamnimitr, P., Thammatorn, W., U-thoomporn, S., Tattiyapong, P., \& Surachetpong, W. (2018). Non-lethal sampling for Tilapia Lake Virus detection by RT-qPCR and cell culture. Aquaculture, 486, 75-80. doi:https://doi.org/10.1016/j. aquaculture.2017.12.015

Mugimba, K. K., Lamkhannat, M., Dubey, S., Mutoloki, S., Munang'andu, H. M., \& Evensen, Ø. (2020). Tilapia lake virus downplays innate immune responses during early stage of infection in Nile tilapia (Oreochromis niloticus). Scientific Reports, 10(1), 20364. doi:10.1038/s41598-020-73781-y

Mugimba, K. K., Tal, S., Dubey, S., Mutoloki, S., Dishon, A., Evensen, O., \& Munang'andu, H. M. (2019). Gray (Oreochromis niloticus x O. aureus) and Red (Oreochromis spp.) Tilapia show equal susceptibility and proinflammatory cytokine responses to experimental Tilapia Lake Virus infection. Viruses, 11(10). doi:10.3390/v11100893

Nicholson, P., Fathi, M. A., Fischer, A., Mohan, C., Schieck, E., Mishra, N., . . Jores, J. (2017). Detection of Tilapia Lake Virus in Egyptian fish farms experiencing high mortalities in 2015. Journal of Fish Diseases, 40(12), 1925-1928. doi:10.1111/jfd.12650

Nicholson, P., Mon-on, N., Jaemwimol, P., Tattiyapong, P., \& Surachetpong, W. (2020). Coinfection of tilapia lake virus and Aeromonas hydrophila synergistically increased mortality and worsened the disease severity in tilapia (Oreochromis spp.). Aquaculture, 520, 734746. doi:https://doi.org/10.1016/j.aquaculture.2019.734746

OIE. (2018). Tilapia Lake Virus ( T i L V) - A Novel Orthomyxo-Like Virus. OIE, Paris. OIE technical disease card. Retrieved from https://www.oie.int/fileadmin/Home/eng/Internationa_Standard_Setting/docs/pdf/A_TiL V_disease_card.pdf

Pierezan, F., Yun, S., Piewbang, C., Surachetpong, W., \& Soto, E. (2020). Pathogenesis and immune response of Nile tilapia (Oreochromis niloticus) exposed to Tilapia lake virus by intragastric route. Fish \& Shellfish Immunology, 107, 289-300. doi:https://doi.org/10.1016/j.fsi.2020.10.019

Rao, M., Kumar, S. H., Kumar, S., Bedekar, M. K., Tripathi, G., \& Kooloth Valappil, R. (2021). Microbiological investigation of Tilapia lake virus-associated mortalities in cage-farmed 
Oreochromis niloticus in India. Aquaculture International. doi:10.1007/s10499-02000635-9

Sollid, S. A., Lorz, H. V., Stevens, D. G., \& Bartholomew, J. L. (2003). Age-Dependent susceptibility of chinook salmon to Myxobolus cerebralis and effects of sustained parasite challenges. Journal of Aquatic Animal Health, 15(2), 136-146. doi:10.1577/H02-038

Sood, N., Verma, D.K., Paria, A., Yadav, S.C., Yadav, M.K., Bedekar, M.K., Kumar, S., Swaminathan, T.R., Mohan, C.V., Rajendran, K.V., \& Pradhan, P.K. (2021). Transcriptome analysis of liver elucidates key immune-related pathways in Nile tilapia Oreochromis niloticus following infection with tilapia lake virus. Fish Shellfish Immunol, 111, 208-219. doi: 10.1016/j.fsi.2021.02.005

Surachetpong, W., Janetanakit, T., Nonthabenjawan, N., Tattiyapong, P., Sirikanchana, K., \& Amonsin, A. (2017). Outbreaks of Tilapia Lake Virus Infection, Thailand, 2015-2016. Emerging Infectious Diseases, 23(6), 1031-1033. doi:10.3201/eid2306.161278

Surachetpong, W., Roy, S. R. K., \& Nicholson, P. (2020). Tilapia lake virus: The story so far. Journal of Fish Diseases. 43(10), 1115-1132. doi:https://doi.org/10.1111/jfd.13237

Tattiyapong, P., Dachavichitlead, W., \& Surachetpong, W. (2017). Experimental infection of Tilapia Lake Virus (TiLV) in Nile tilapia (Oreochromis niloticus) and red tilapia (Oreochromis spp.). Veterinary Microbiology, 207, 170-177. doi:10.1016/j.vetmic.2017.06.014

Tattiyapong, P., Sirikanchana, K., \& Surachetpong, W. (2018). Development and validation of a reverse transcription quantitative polymerase chain reaction for tilapia lake virus detection in clinical samples and experimentally challenged fish. Journal of Fish Diseases, 41(2), 255-261. doi:10.1111/jfd. 12708

Timmerhaus, G., Krasnov, A., Nilsen, P., Alarcon, M., Afanasyev, S., Rode, M., . . Jørgensen, S. M. (2011). Transcriptome profiling of immune responses to cardiomyopathy syndrome (CMS) in Atlantic salmon. BMC Genomics, 12(1), 459. doi:10.1186/1471-2164-12-459

Waiyamitra, P., Zoral, M. A., Saengtienchai, A., Luengnaruemitchai, A., Decamp, O., Gorgoglione, B., \& Surachetpong, W. (2020). Probiotics modulate tilapia resistance and immune response against Tilapia Lake Virus infection. Pathogens, 9(11). doi:10.3390/pathogens9110919

Yamkasem, J., Tattiyapong, P., Kamlangdee, A., \& Surachetpong, W. (2019). Evidence of potential vertical transmission of tilapia lake virus. Journal of Fish Diseases, 42(9), 12931300. doi:10.1111/jfd.13050 
415 Figure 1. Cumulative mortality of the $5 \mathrm{~g}, 25 \mathrm{~g}$, and $65 \mathrm{~g}$ red hybrid tilapia after the TiLV

416 challenge. At the density of $5 \mathrm{~g} / \mathrm{L}$, sixty fish from each weight group were equally divided into

417 two $150 \mathrm{~L}$ tanks (for $5 \mathrm{~g}$ fish), three $150 \mathrm{~L}$ tanks (for $25 \mathrm{~g}$ fish), and six $150 \mathrm{~L}$ tanks (for $65 \mathrm{~g}$ fish).

418 Then, fish were intraperitoneally (IP) injected with $50 \mu \mathrm{L}$ of TiLV at 105 TCID50/mL. Mortality

419 data were recorded from individual tanks and presented as a mean and SE from each weight group.

420 The challenge studies were performed at 1,2, and 3 months when fish were allowed to grow to the 421 expected size in our animal facility until they reached $5 \mathrm{~g}, 25 \mathrm{~g}$, and $65 \mathrm{~g}$ respectively. The clinical

422 signs and daily mortality were observed and recorded for 21 days. Mortality data from different

423 sizes of fish were compared using one-way ANOVA with Tukey's multiple comparisons test. An

424 asterisk $(*)$ indicates a statistical difference $(\mathrm{p}<0.05)$.

425 Figure 2. Comparison of TiLV RNA concentrations in TiLV-IP challenged fish. The amount of 426 TiLV RNA was analyzed from the liver of $5 \mathrm{~g}, 25 \mathrm{~g}$, and $65 \mathrm{~g}$ fish $(\mathrm{n}=8)$ at $7 \mathrm{dpi}$ and fish $(\mathrm{n}=7)$

427 at 14 and 22 dpi. The liver of fish $(n=3)$ was collected from the $5 \mathrm{~g}, 25 \mathrm{~g}$, and $65 \mathrm{~g}$ groups at 0

428 dpi prior to the TiLV challenge to demonstrate the TiLV status of the fish. The viral concentration

429 from different sizes of fish and different time points were compared using one-way ANOVA with 430 Tukey's multiple comparisons test. The asterisks indicate a statistical difference $(* * p<0.01, * * *$ $431 p<0.001)$.

432 Figure 3. Histopathology score of liver, spleen, and intestine of normal and TiLV-IP challenge 433 fish. Representative histopathology of(A) Liver. (E) Spleen. (I) Intestine of normal fish. (B) TiLV434 IP challenge fish showed degeneration and necrosis of hepatocytes, and depletion of glycogen in 435 hepatocytes. (C) Syncytial hepatic cells (arrowhead). (D) Eosinophilic intracytoplasmic inclusion 436 bodies (arrow). (F) The spleen of TiLV-IP challenge fish showed red blood cell depletion. (G) 437 Increased melanomacrophage centers. (H) Eosinophilic intracytoplasmic inclusion bodies (red 
438 arrow). (J) The intestine of TiLV-IP challenge fish showed infiltration of lymphocytes in lamina 439 propria. (K) Sloughing of intestinal epithelial cells (L) Goblet cell hyperplasia. Histopathological 440 scores in organs of each weight group $(n=3)$ were evaluated $(M)$ at 7 dpi. (N) at 14 dpi.

441 Figure 4. Cumulative mortality of the $5 \mathrm{~g}$ and $25 \mathrm{~g}$ red hybrid tilapia after the TiLV cohabitation 442 challenge. Fish $(n=30)$ from each group were cohabitated with an inducer $(n=10)$. Clinical signs 443 and daily mortality were observed and recorded for 28 days. Mortality data from $5 \mathrm{~g}$ and $25 \mathrm{~g}$ fish 444 were compared using one-way ANOVA with Tukey's multiple comparisons test. An asterisk (*) 445 indicates a statistical difference $(\mathrm{p}<0.05)$. An asterisk $(*)$ indicates a statistical difference $(p<$ 446 0.05).

\section{Supplementary Information}

Figure S1. Gross pathology of TiLV-IP challenge fish. Representative figures of (A-C) $5 \mathrm{~g}$ red 450 hybrid tilapia. (D-F) $25 \mathrm{~g}$ red hybrid tilapia. (G-I) $65 \mathrm{~g}$ red hybrid tilapia.

Figure S2. Representative histopathological lesions of liver, spleen, and intestine of TiLV-IP 452 challenge fish. (A, E, I) Normal liver, spleen and intestine of control fish. (B-D) Liver of TiLVIP challenge fish with mild, moderate, and severe lesions. $(\mathrm{F}-\mathrm{H})$ Spleen of TiLV-IP challenge fish 454 with mild, moderate, and severe lesions. (J-L) Intestine of TiLV-IP challenge fish with mild, 455 moderate, and severe lesions. Lesion scores were graded according to criteria described in Table 456 1. 
Figure 1

Cumulative mortality of the $5 \mathrm{~g}, 25 \mathrm{~g}$, and $65 \mathrm{~g}$ red hybrid tilapia after the TiLV challenge.

At the density of $5 \mathrm{~g} / \mathrm{L}$, sixty fish from each weight group were equally divided into two $150 \mathrm{~L}$ tanks (for $5 \mathrm{~g}$ fish), three $150 \mathrm{~L}$ tanks (for $25 \mathrm{~g}$ fish), and six $150 \mathrm{~L}$ tanks (for $65 \mathrm{~g}$ fish). Then, fish were intraperitoneally (IP) injected with $50 \mu \mathrm{L}$ of TiLV at $105 \mathrm{TCID} 50 / \mathrm{mL}$. Mortality data were recorded from individual tank and presented as a mean and SE from each weight group. The challenge studies was performed at 1,2, and 3 months when fish were allowed to grow to the expected size in our animal facility until they reached $5 \mathrm{~g}, 25 \mathrm{~g}$, and $65 \mathrm{~g}$ respectively. The clinical signs and daily mortality were observed and recorded for 21 days. Mortality data from different size of fish was compared using one-way ANOVA with Tukey's multiple comparisons test. An asterisk $(*)$ indicates a statistical difference $(p<0.05)$.

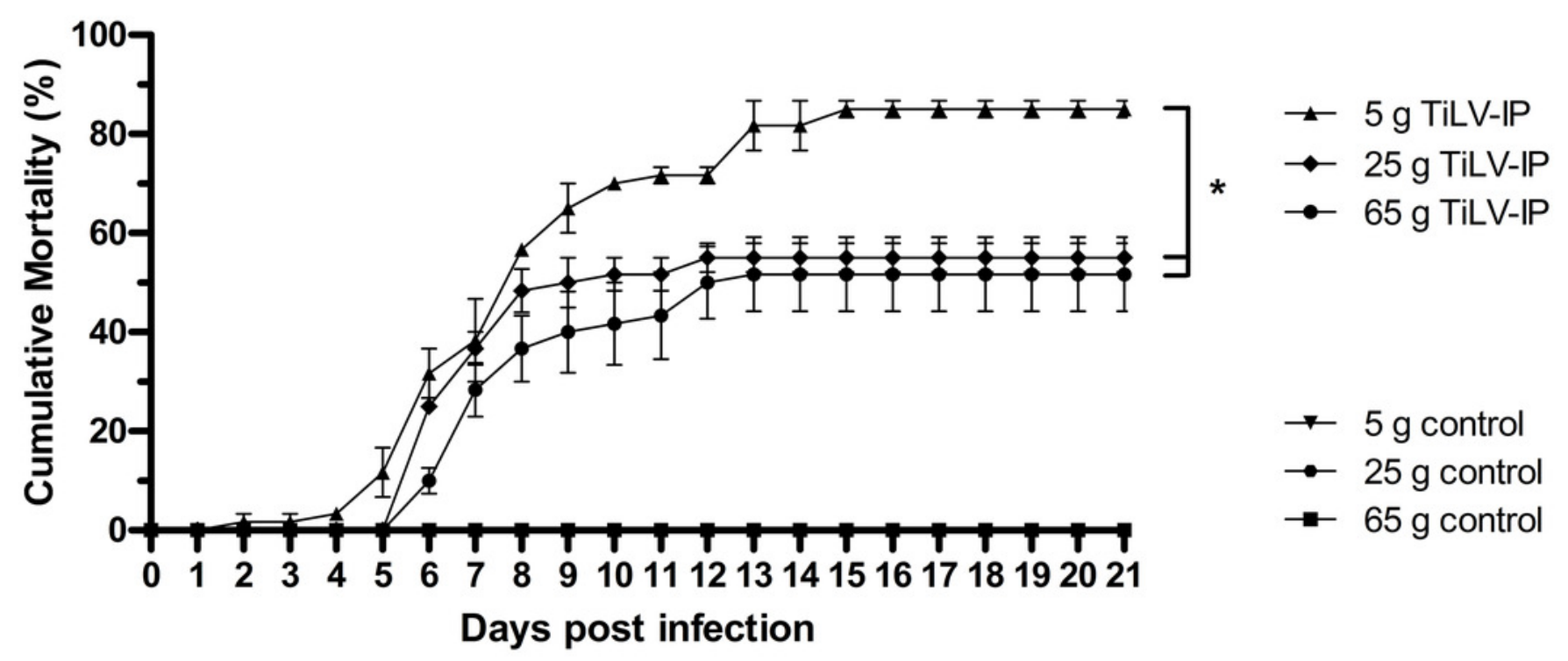


Figure 2

Comparison of TiLV RNA concentrations in TiLV-IP challenge fish.

The amount of TiLV RNA was analyzed from the liver of $5 \mathrm{~g}, 25 \mathrm{~g}$, and $65 \mathrm{~g}$ fish $(\mathrm{n}=8)$ at 7 dpi and fish ( $n=7)$ at 14 and $22 \mathrm{dpi}$. The liver of fish $(n=3)$ were collected from the $5 \mathrm{~g}, 25$ $\mathrm{g}$, and $65 \mathrm{~g}$ groups at $0 \mathrm{dpi}$ prior to the TiLV challenge to demonstrate the TiLV status of the fish. The viral concentration from different size of fish and different time points were compared using one-way ANOVA with Tukey's multiple comparisons test. The asterisks indicate a statistical difference $(* * p<0.01, * * * p<0.001)$.

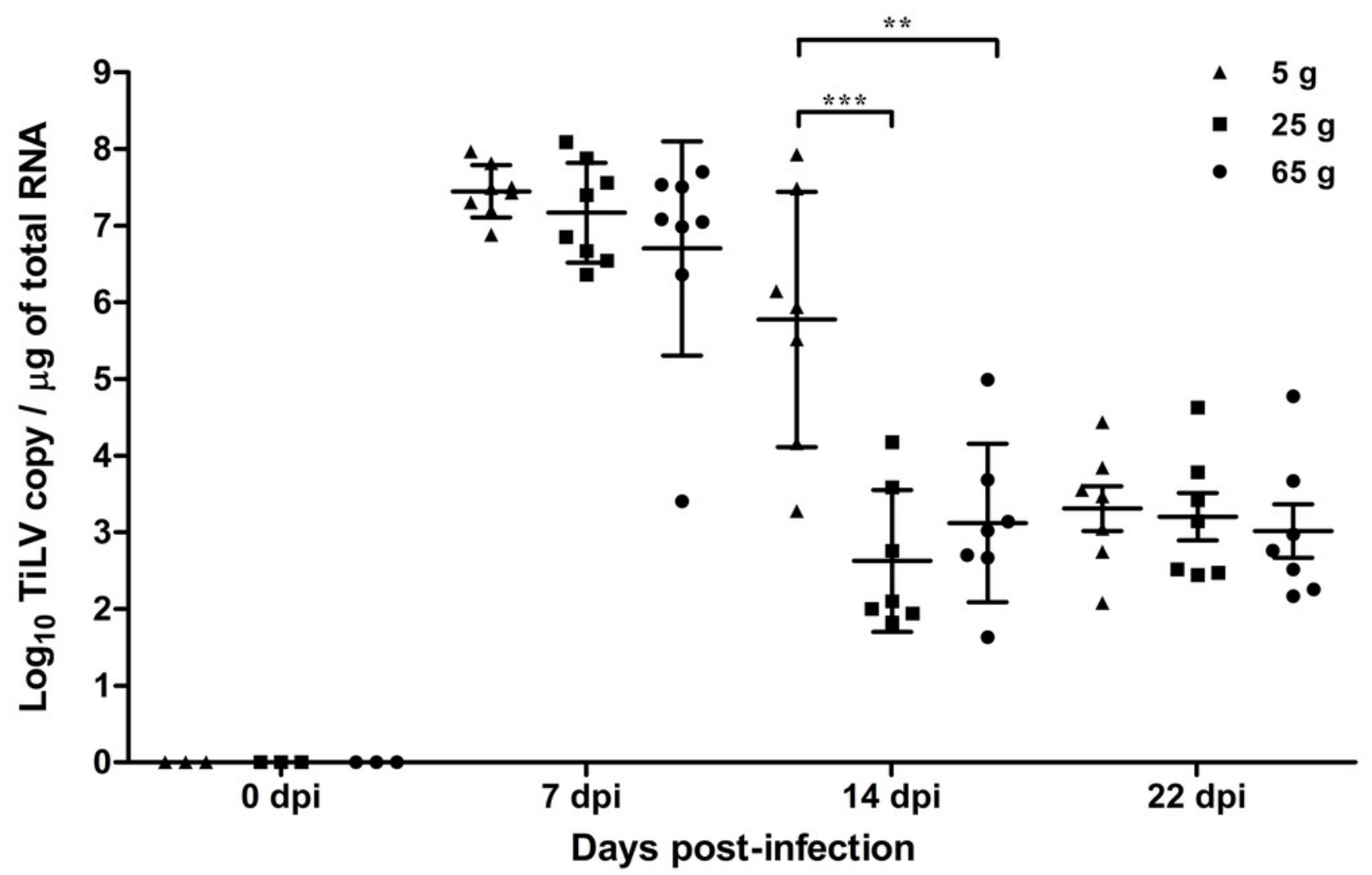




\section{Figure 3}

Histopathology score of liver, spleen, and intestine of normal and TiLV-IP challenge fish.

Representative histopathology of (A) Liver. (E) Spleen. (I) Intestine of normal fish. (B) TiLV-IP challenge fish showed degeneration and necrosis of hepatocytes, and depletion of glycogen in hepatocytes. (C) Syncytial hepatic cells (arrow head). (D) Eosinophilic intracytoplasmic inclusion bodies (arrow). (F) The spleen of TiLV-IP challenge fish showed red blood cell depletion. (G) Increased melanomacrophage centers. (H) Eosinophilic intracytoplasmic inclusion bodies (red arrow). (J) The intestine of TiLV-IP challenge fish showed infiltration of lymphocyte in lamina propria. (K) Sloughing of intestinal epithelial cells (L) Goblet cell hyperplasia. Histopathological scores in organs of each weight group $(n=3)$ were evaluated (M) at $7 \mathrm{dpi}$. (N) at $14 \mathrm{dpi}$. 


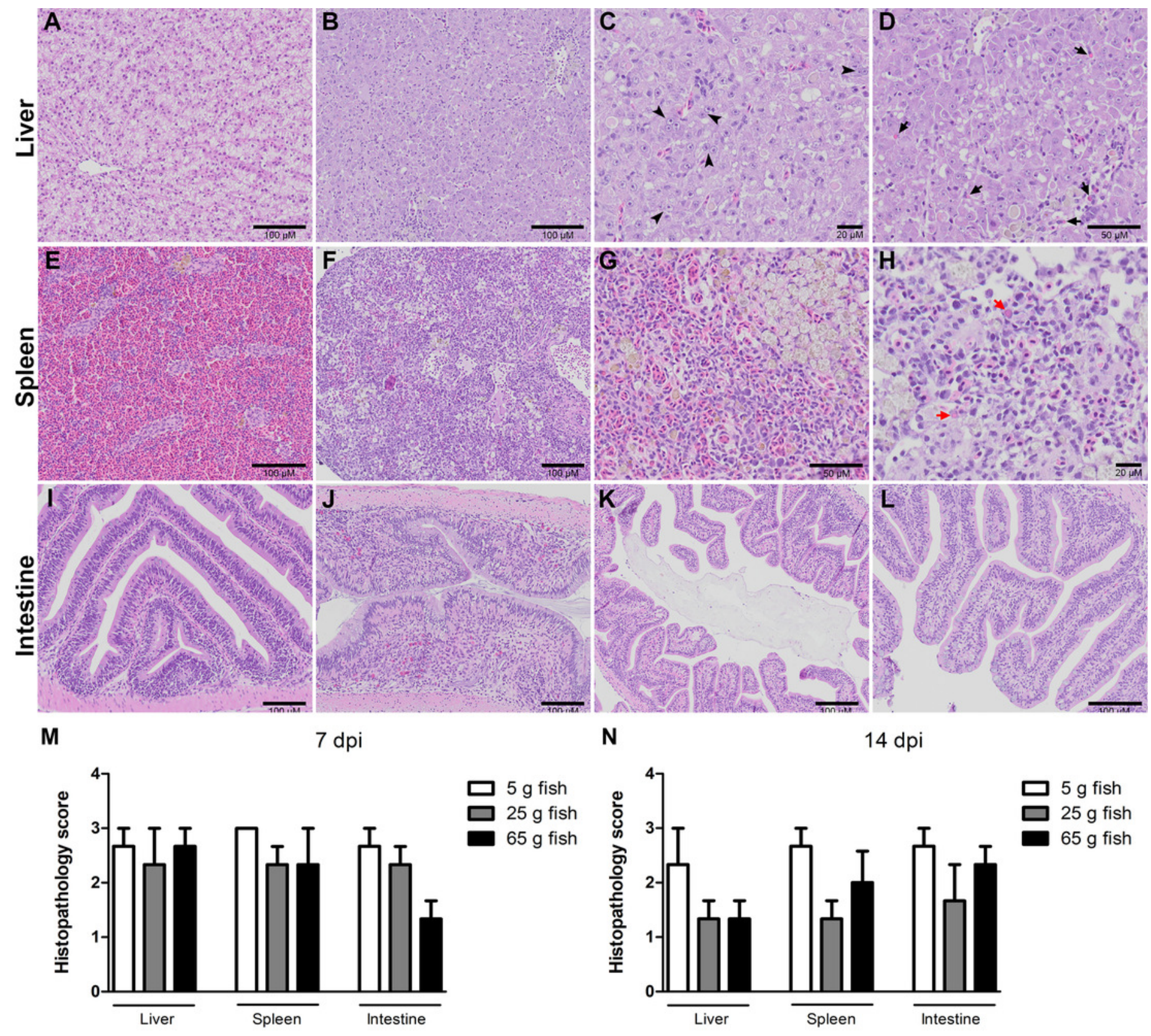


Figure 4

Cumulative mortality of the $5 \mathrm{~g}$ and $25 \mathrm{~g}$ red hybrid tilapia after the TiLV cohabitation challenge.

Fish $(n=30)$ from each group were cohabitated with an inducer $(n=10)$. Clinical signs and daily mortality were observed and recorded for 28 days. Mortality data from $5 \mathrm{~g}$ and $25 \mathrm{~g}$ fish was compared using one-way ANOVA with Tukey's multiple comparisons test. An asterisk (*) indicates a statistical difference $(p<0.05)$. An asterisk $(*)$ indicates a statistical difference $(p$ $<0.05)$.

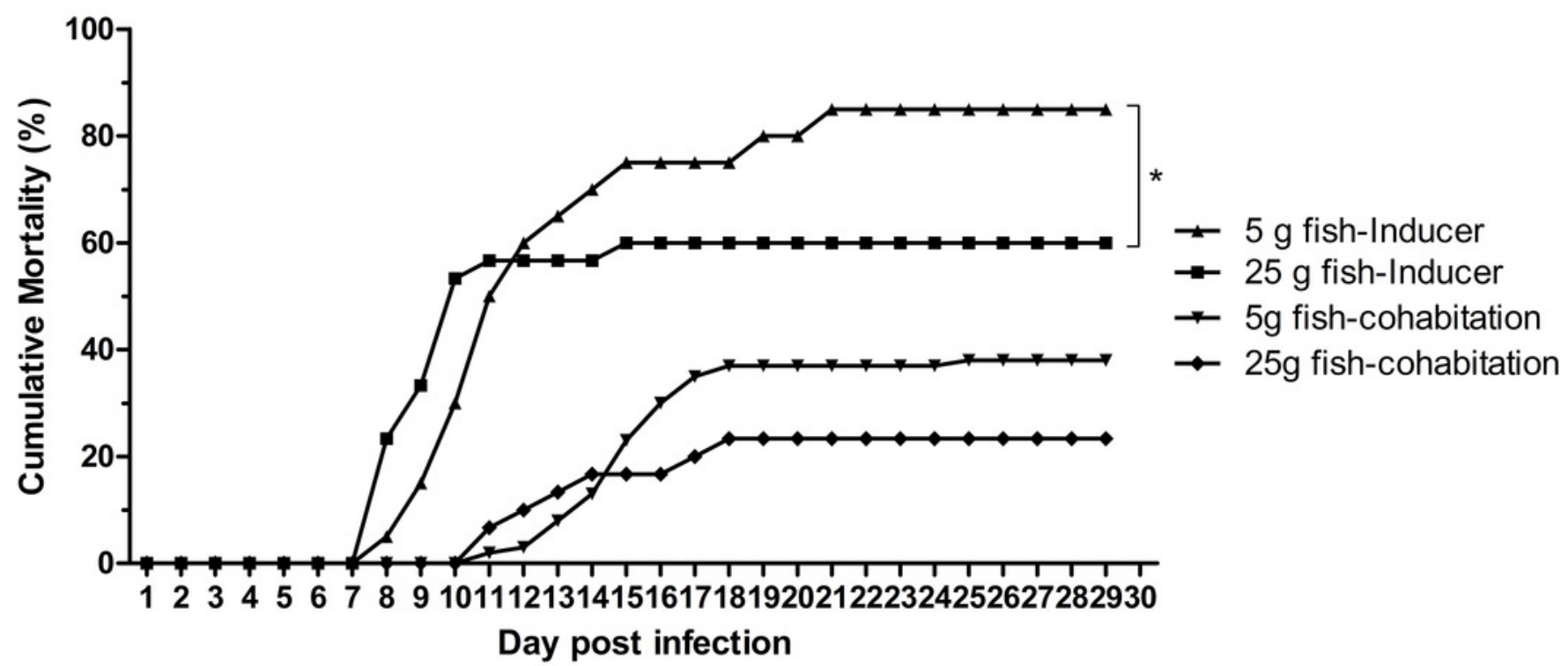


Table $\mathbf{1}$ (on next page)

Histopathology scoring system. 
1 Table 1. Histopathology scoring system.

\begin{tabular}{|c|c|c|c|c|}
\hline \multirow{2}{*}{ Score } & \multirow{2}{*}{ Severity } & \multicolumn{3}{|l|}{ Tissue } \\
\hline & & Liver & Spleen & Intestine \\
\hline 0 & Absent & normal & normal & normal \\
\hline 1 & Mild & $\begin{array}{l}10-20 \% \text { liver cells degeneration and necrosis } \\
0-3 \text { syncytial cells } \\
0-3 \text { intracytoplasmic inclusion bodies }\end{array}$ & $10-20 \%$ red blood cell depletion & $\begin{array}{l}10-20 \% \text { infiltration of lymphocyte in } \\
\text { lamina propria }\end{array}$ \\
\hline \multirow[t]{3}{*}{2} & \multirow[t]{3}{*}{ Moderate } & $\begin{array}{l}20-40 \% \text { liver cells degeneration and necrosis } \\
20-40 \% \text { depletion of glycogen in hepatocytes }\end{array}$ & $\begin{array}{l}20-40 \% \text { red blood cell depletion } \\
10 \% \text { increase melanomacrophage centers }\end{array}$ & $\begin{array}{l}10-20 \% \text { infiltration of lymphocyte in } \\
\text { lamina propria }\end{array}$ \\
\hline & & 4-10 syncytial cells & $1-5$ intracytoplasmic inclusion bodies & $\begin{array}{l}\text { 10-20\% sloughing of intestinal } \\
\text { epithelial cells }\end{array}$ \\
\hline & & 4-7 intracytoplasmic inclusion bodies & & $20-40 \%$ goblet cell hyperplasia \\
\hline \multirow[t]{3}{*}{3} & \multirow[t]{3}{*}{ Severe } & $\begin{array}{l}>40 \% \text { liver cells degeneration and necrosis } \\
>40 \% \text { depletion of glycogen in hepatocytes }\end{array}$ & $\begin{array}{l}>40 \% \text { red blood cell depletion } \\
>10 \% \text { increase melanomacrophage centers }\end{array}$ & $\begin{array}{l}10-20 \% \text { infiltration of lymphocyte in } \\
\text { lamina propria }\end{array}$ \\
\hline & & $>10$ syncytial cells & $>5$ intracytoplasmic inclusion bodies & $\begin{array}{l}>40 \% \text { sloughing of intestinal epithelial } \\
\text { cells }\end{array}$ \\
\hline & & $>7$ intracytoplasmic inclusion bodies & & $>40 \%$ goblet cell hyperplasia \\
\hline
\end{tabular}




\section{Table 2 (on next page)}

Pathological scores of liver, spleen, and intestine in TiLV-challenge tilapia.

* The pathological scores were categorized as mild (1), moderate (2), and severe (3) changes according to the scoring system mentioned in Table1. The scores were categorized after examing three fish per weight group per time point and statistically analyzed by nonparametric Mann-Whitney test. 
1 Table 2. Pathological scores of liver, spleen, and intestine in TiLV-challenge tilapia.

\begin{tabular}{|c|c|c|c|c|c|}
\hline \multirow[b]{3}{*}{ Fish weight } & \multirow[b]{3}{*}{ Organs } & \multicolumn{4}{|c|}{ Pathological scores* } \\
\hline & & \multicolumn{2}{|r|}{$7 \mathrm{dpi}$} & \multicolumn{2}{|r|}{$14 \mathrm{dpi}$} \\
\hline & & Scores & $\begin{array}{l}\text { Number of } \\
\text { affected fish/total } \\
\text { fish }\end{array}$ & Scores & $\begin{array}{l}\text { Number of } \\
\text { affected fish/total } \\
\text { fish }\end{array}$ \\
\hline \multirow[t]{6}{*}{$5 \mathrm{~g}$} & Liver & 3 & $2 / 3$ & 3 & $2 / 3$ \\
\hline & & 2 & $1 / 3$ & 1 & $1 / 3$ \\
\hline & Spleen & 3 & $3 / 3$ & 3 & $2 / 3$ \\
\hline & & & & 2 & $1 / 3$ \\
\hline & Intestine & 3 & $2 / 3$ & 3 & $2 / 3$ \\
\hline & & 2 & $1 / 3$ & 2 & $1 / 3$ \\
\hline \multirow[t]{6}{*}{$25 \mathrm{~g}$} & Liver & 3 & $2 / 3$ & 2 & $1 / 3$ \\
\hline & & 1 & $1 / 3$ & 1 & $2 / 3$ \\
\hline & Spleen & 3 & $1 / 3$ & 2 & $1 / 3$ \\
\hline & & 2 & $2 / 3$ & 1 & $2 / 3$ \\
\hline & Intestine & 3 & $1 / 3$ & 3 & $1 / 3$ \\
\hline & & 2 & $2 / 3$ & 1 & $2 / 3$ \\
\hline \multirow[t]{7}{*}{$65 \mathrm{~g}$} & Liver & 3 & $2 / 3$ & 2 & $1 / 3$ \\
\hline & & 2 & $1 / 3$ & 1 & $2 / 3$ \\
\hline & Spleen & 3 & $2 / 3$ & 3 & $1 / 3$ \\
\hline & & 1 & $1 / 3$ & 2 & $1 / 3$ \\
\hline & & & & 1 & $1 / 3$ \\
\hline & Intestine & 2 & $1 / 3$ & 3 & $1 / 3$ \\
\hline & & 1 & $2 / 3$ & 2 & $2 / 3$ \\
\hline
\end{tabular}

* The pathological scores were categorized as mild (1), moderate (2), and severe (3) changes according to the scoring system mentioned in Table1. The scores were categorized after examing three fish per weight group per time point and statistically analyzed by nonparametric Mann-Whitney test. 